\title{
Élményalapú, okostelefonnal támogatott atipikus oktatásmódszertani megoldások a nyitott tananyagfejlesztés kiterjesztésére
}

\section{Bevezetés}

Napjainkra az okostelefonok fejlődésével és előretörésével egyre nagyobb hangsúlyt kapnak a mobil alkalmazások, applikációk, szemben a tradicionális, számítógép alapú programokkal, programkörnyezetekkel. E folyamat hátterében azok a digitalizációval összefüggő jelenségek és tendenciák húzódnak, melyek gyökeresen megváltoztatják a tanulási környezetünket is. A digitális kultúra és az emögött érzékelhető technológiai fejlődési irányvonalak mindinkább mobillá, nyitottá, és medalizálttá teszi az új IKT alapú környezetünket (Benedek, 2016; Molnár, 2014). Ennek egyik markáns megjelenési formája a médiakonvergencia, az online, internetes és mobilalapú kommunikáció beépülése a mindennapjainkban (Szúts, 2018), mely nem csupán a digitális állampolgárok körében tapasztalható meg. Számos cég és fejlesztő felismerte időben és követte ezeket a trendeket, melynek köszönhetően alkalmazásaik elérhetővé váltak a különböző okostelefonon futó operációs rendszerek, platformok piacterein. Ezekről a piacterekről különböző konstrukcióban tölthetjük le az alkalmazásokat, ilyen például az ingyenes, az ingyenes reklámokkal, az ingyenes fizetős komponensekkel, vagy a teljesen fizetős applikáció.

Ilyen típusú alkalmazásokat a megfelelő szakismeret elsajátítása után szinte már bárki fejleszthet a mai tartalom előállítási kommunikációs modellünkben, és az egyes platformok fejlesztési irányelveinek betartása esetén a kész applikáció meg is jelenhet az adott platform piacterén. Ha az alkalmazást fizetősnek szánja a fejlesztő, akkor a bevételből meghatározott arányban részesedést is kaphat, a platformszolgáltatóval megosztva.

\section{1. ábra: Okostelefon platformok piaci részesedése 2009-2016 között [1]}

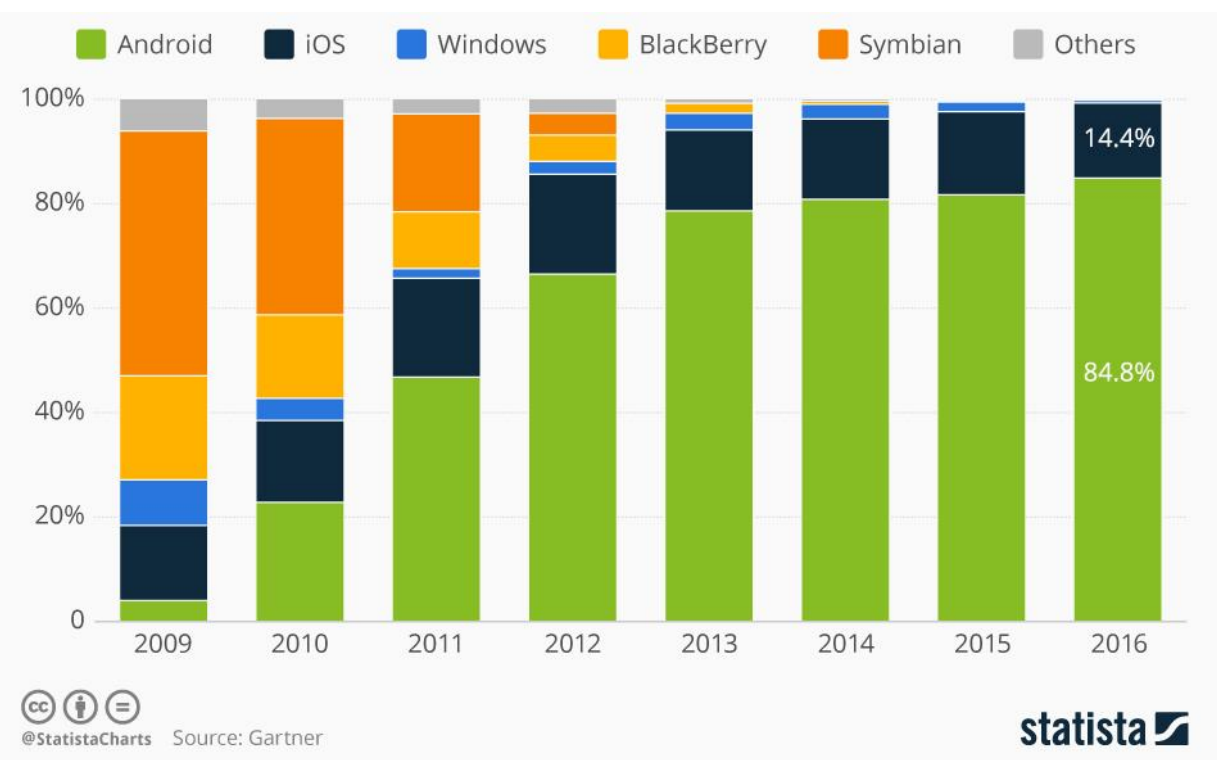

Érdemes szem előtt tartani az egyes szereplők piaci arányát is. 2010-ben még egy viszonylag kiegyenlített piacon versenyzett egymással az Android, iOS, Blackberry és Symbian platform. 2018 végére a Google Android platformjának $86 \%$ a részesedése, az Apple iOS platformjának 13\% a 
részesedése, míg a további platformoké a maradék 1\%. Így egy adott alkalmazás Android és iOS verziójának elkészítése esetén le is fedtük a piac 99\%-át. (Smartphone Market Share, 2018) Az elmúlt években egyre elterjedtebbé vált, az úgynevezett crossplatform fejlesztés is, melynek segítségével már nem külön kell fejleszteni a két platformra, hanem közös kódbázisból generálódik ki az alkalmazás a különböző operációs rendszerekre.

\section{Okostelefonok világa}

Az okostelefonok térhódítása 2007-ben az iPhone megjelenésével kezdődött el, és változtatta meg alapjaiban véve a társadalmat, a kommunikációs és eszközhasználati szokásainkat, vagyis megreformálta a világot. Napjainkra már több tartalmat néznek mobiltelefonon keresztül, mint hagyományos asztali, illetve hordozható számítógépes környezetben.

Az okostelefonok egyik nagy újítása az érintőképernyő, melyek először egyérintéses változatban, később pedig többérintéses (multi-touch) változatban jelentek meg. Az érintőképernyő megjelenésével számos gesztust is el kellett elsajátítanunk, melyek segítségével vezérelhetjük a telefonunkat és az alkalmazások funkcióit.

\section{2. ábra: Gesztusok az érintőképernyőn [2]}

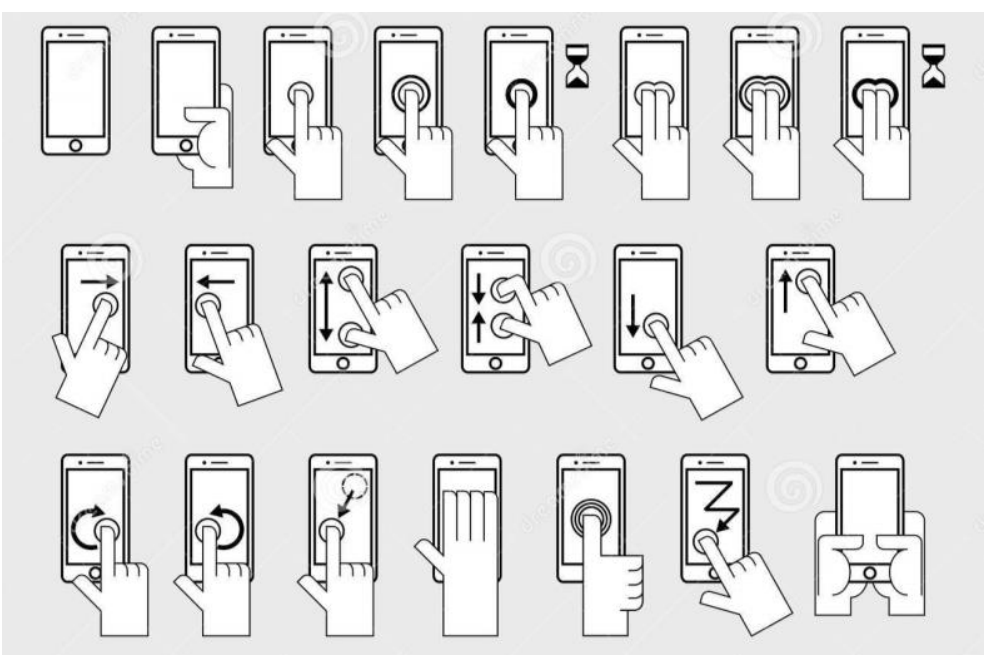

Az érintőképernyő mellett számos további újítás jelent meg a különböző készülékekben az elmúlt évek során. Ilyenek például a különböző kommunikációt támogató technológiák és adapterek: a Bluetooth, a Wi-fi, az NFC, a mobilinternet, az infravörös port stb.

A kommunikációt támogató portok mellett pedig egyre több szenzor került beépítésre az eszközökbe, melyek adatait a különböző applikációk el tudják érni és fel tudják használni a múködésük során. Ilyenek például: kamera, mikrofon, közelségérzékelő, fényérzékelő, GPS, gyorsulásmérő, giroszkóp, mágneses térerősségmérő, hőmérsékletmérő, légnyomásmérő stb. További szenzorok pedig az okostelefonokhoz kiegészítőként beszerezhető okosórákba, fittnesz-karkötőkbe kerültek telepítésre, melyek az egészséges életmódot is támogatni tudják, például pulzusszámmérő, alvásfigyelő. 


\section{3. ábra: Szétszerelt okostelefon a különböző belső alkatrészekkel, szenzorokkal [3]}

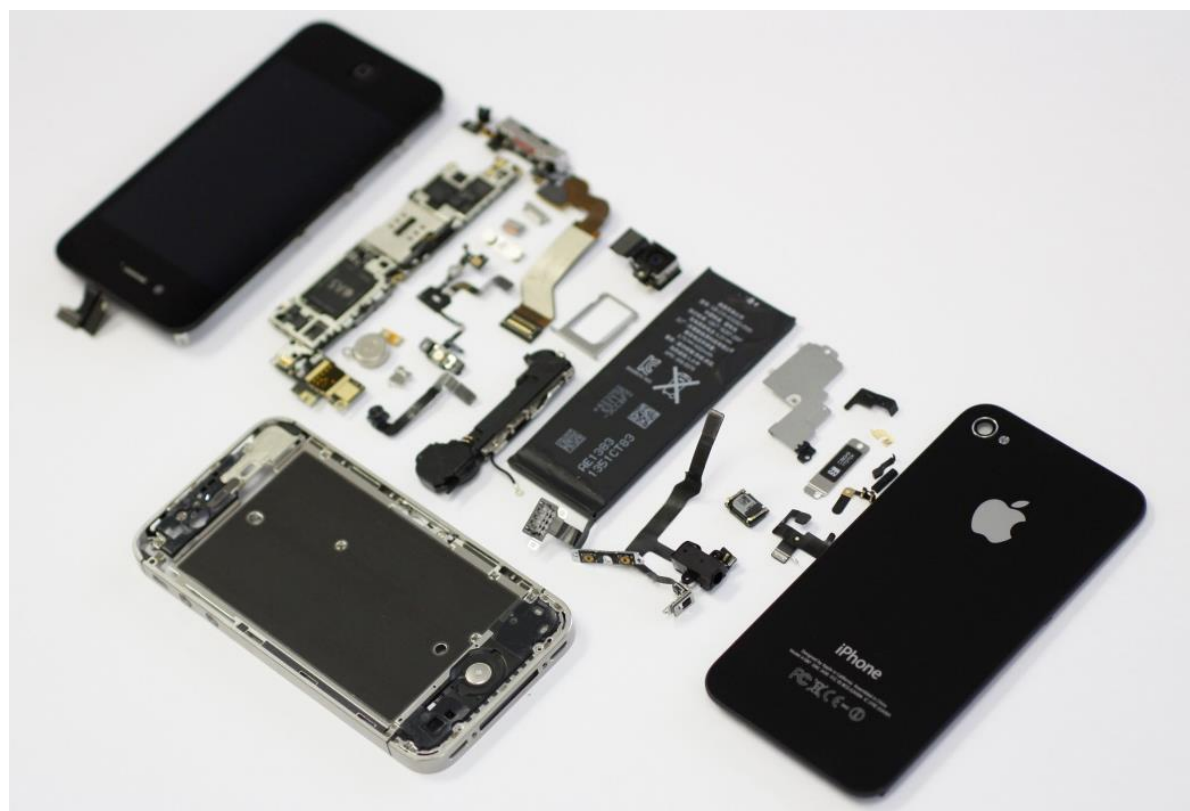

\section{Atipikus tanulási formák és lehetőségek}

Az előző részben felsorolt kommunikációs technológiák és szenzorok kombinációjával számos atipikus formában is alkalmazható megoldás és ráépülő applikáció készült el az elmúlt évek során. Egyik ilyen népszerű terület a virtuális valóság, illetve kiterjesztett valóság alapú alkalmazások világa. Ezeket az oktatás területén is jól lehet hasznosítani, számos eszközt és alkalmazást integráltak sikerrel és használják ki az új technológiában rejlő funkciókat. Jó példák a HP Reveal és a QuiverVision interaktív alkalmazások, melyekkel egy-egy képet, vagy QR-kódot lefényképezve a telefon vagy tablet képernyőjén megjelenik a háromdimenziós tartalom, amit bármilyen irányba körbeforgathatunk, közelíthetünk, távolíthatunk, megtekinthetjük a belső részleteket például egy drótvázas megjelenítési mód esetében. Kiváló alkalmazási példa lehet a kémia órán a kristályrács szerkezetek, matematika órán a különböző geometriai alakzatok szemléltetése, gépészeti alkalmazások esetén pedig akár egy robbantott ábra komponenseinek bemutatása.

\section{4. ábra: HP Reveal és QuiverVision alkalmazás [4][5]}
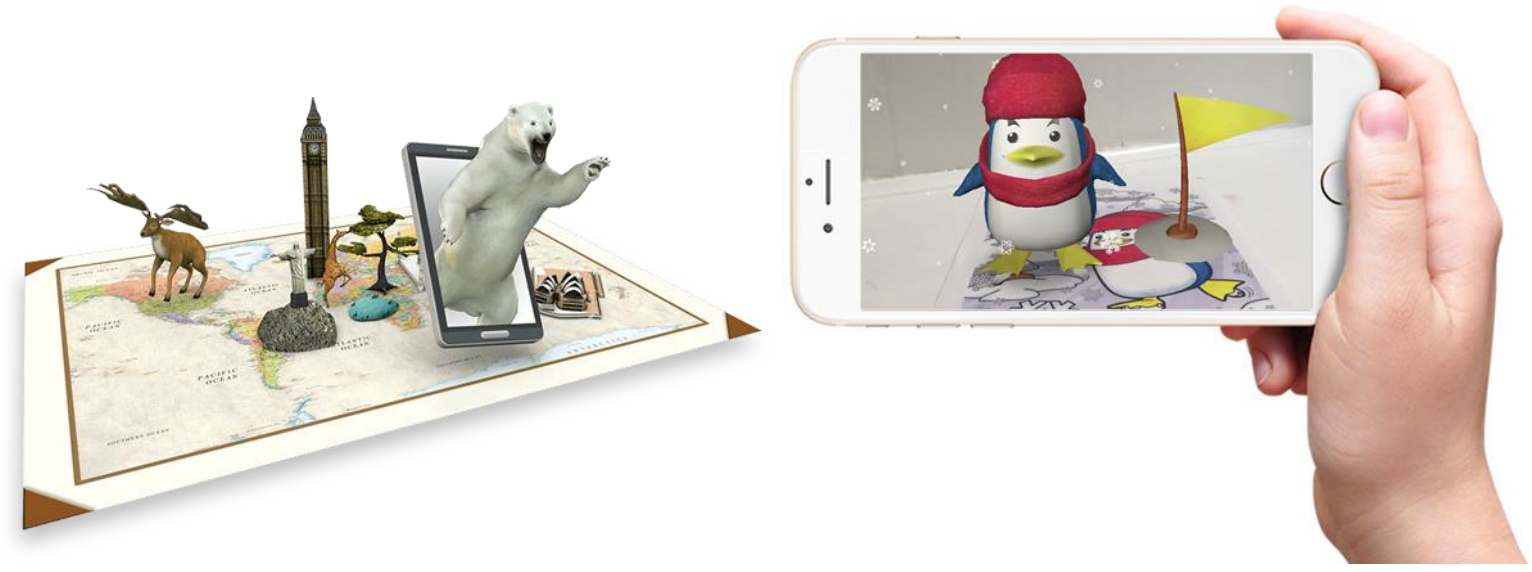

Az oktatás mellett a gamifikáció is egy fontos szempont, melyekkel játékos módon lehet megtanulni pl. a történelmet, megismerni városi látványosságok múltját. Vagy éppen valóban kikapcsolódni kicsit, a gyújteni a szabadban a Pokémonokat a Pokémon Go alkalmazással (Molnár et al., 2018). 
Az okostelefonok képernyőjén túlmutatva pedig a virtuális valóság eszközök tekintetében pedig egyre népszerúbbek a különböző okos-szemüvegek: Google Glass, Oculus Rift, VR, HoloLens, illetve a többfunkciós kamerával és szenzorokkal ellátott Microsoft Kinect vagy a magyar fejlesztésű Leonar3Do rendszer is.

\section{5. ábra: Pokémon Go és a kiterjesztett valóság [6]}

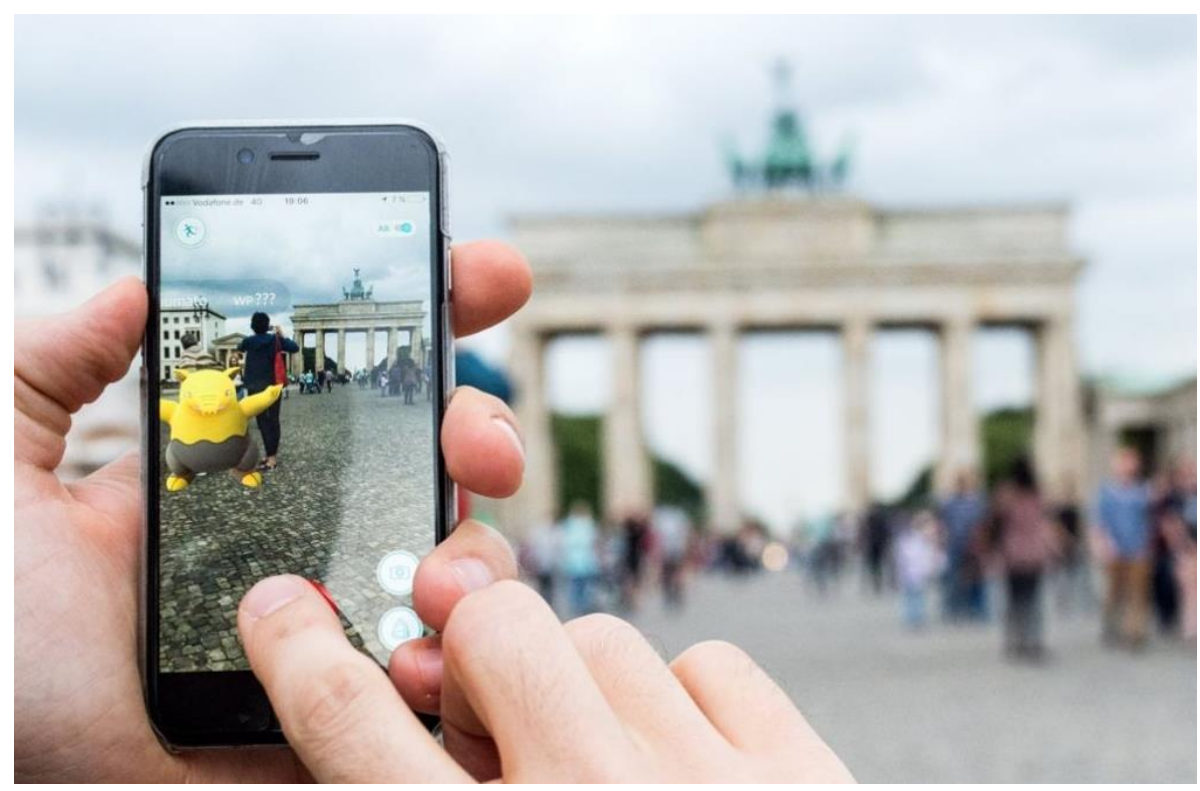

Sokat segítenek, főleg az mobilalkalmazás fejlesztések tekintetében a különböző szimulációs és emulációs eszközök. Ezek felhasználásával nem kell a konkrét okostelefonon, tableten, komplex mérőrendszereken vagy más eszközökön fejleszteni és tesztelni, hanem elég az egészet egy virtuális környezetben megoldani. Erre példa a telefonos alkalmazások esetén a fejlesztőkörnyezetbe beépített emulátor, amivel a számítógép képernyőjén látjuk az okostelefont és tudjuk kipróbálni a funkciókat, másik példa a National Instruments LabVIEW környezete, ahol egy grafikus programozási nyelv segítségével lehet összeállítani a virtuális laboratóriumot, illetve mérési környezetet.

\section{6. ábra: Android okostelefon emulátor és LabVIEW ipari integrált fejlesztői környezet [7][8]}
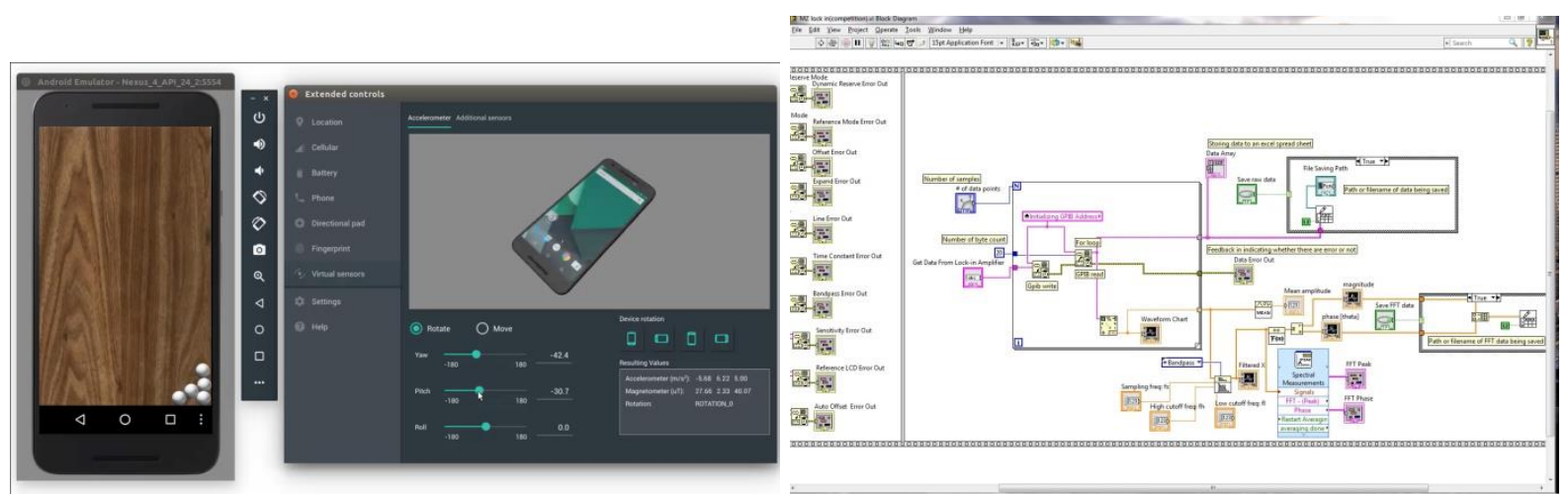

Napjainkra már az is elérhetővé vált, hogy asztali számítógép helyett a monitorunkat, billentyŭzetünket és egerünket egy adapter segítségével a mobiltelefonunkhoz csatlakoztassuk és az így összeállt rendszer váljon a mindennapi számítógépes környezetünkké. Természetesen erőforrás igényes műveletek esetén figyelembe kell venni a mobiltelefonba épített processzor, memória és háttértár esetleges korlátait. 


\section{7. ábra: Mobiltelefonunk, mint asztali számítógép [9]}

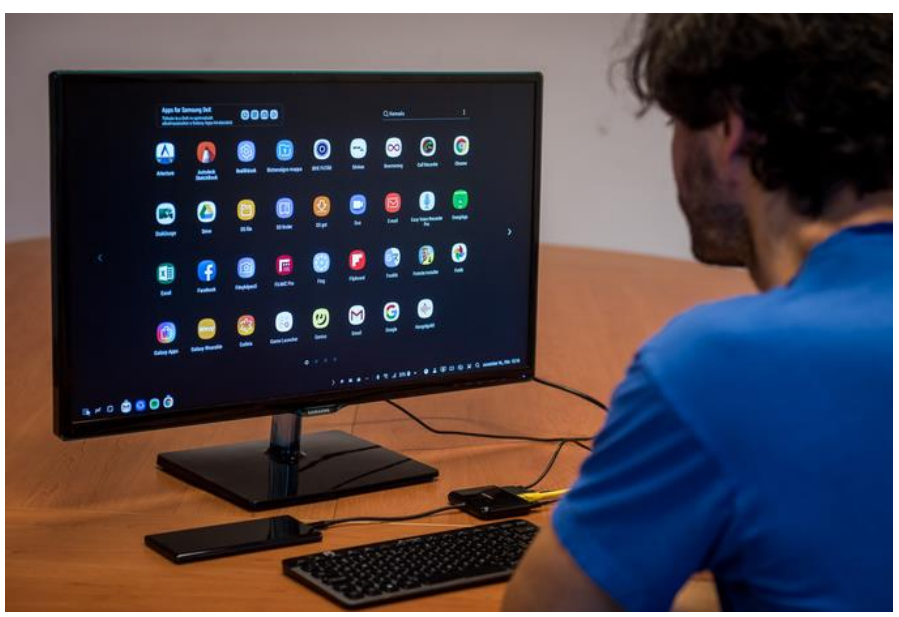

A következőkben néhány további, élményalapú oktatást támogató eszközre is kitérünk a teljesség igénye nélkül. Mind a köznevelésben, mind a felsőoktatásban nagy felhasználóbázisra tettek szert a különböző hallgatói visszajelzést segítő, szavazó- és feleltetőrendszert megvalósító alkalmazások.

Egyik ilyen példa a svéd fejlesztésű Kahoot, ami egy feleletválasztós verseny alapú kvízrendszert valósít meg. Különböző kérdéssorok állíthatók össze, egy vagy több jó válasszal, maximum négy válaszlehetőséggel. A kérdés és a válaszok megjeleníthetők a tanári gépen vagy kivetítőn, a válaszok gombjai pedig a tanulók eszközének (telefon, tablet, számítógép) képernyőjén. A helyes válasz eltalálása mellett a reakcióidő is számít a pontgyújtő rendszerben (Molnár, 2016).

Hasonló alkalmazás a Mentimeter is, ahol a cél a versenyzés helyett inkább a felmérés és az eredmények azonnali megjelenítése és a kooperatív közös gondolkodás és munka. Lehet vele kvízalapú kérdést, nyitott és zárt kérdések feltevését, szófelhő készítést, szöveges válaszbekérést, reakció visszajelzést is megvalósítani, hasonlóan telefon, tablet vagy számítógépes eszközökkel, mint a Kahoot esetében, az eredmények pedig a tanári gépen vagy kivetítőn jelennek meg.

\section{8. ábra: Kahoot és Mentimeter alkalmazások [10][11]}
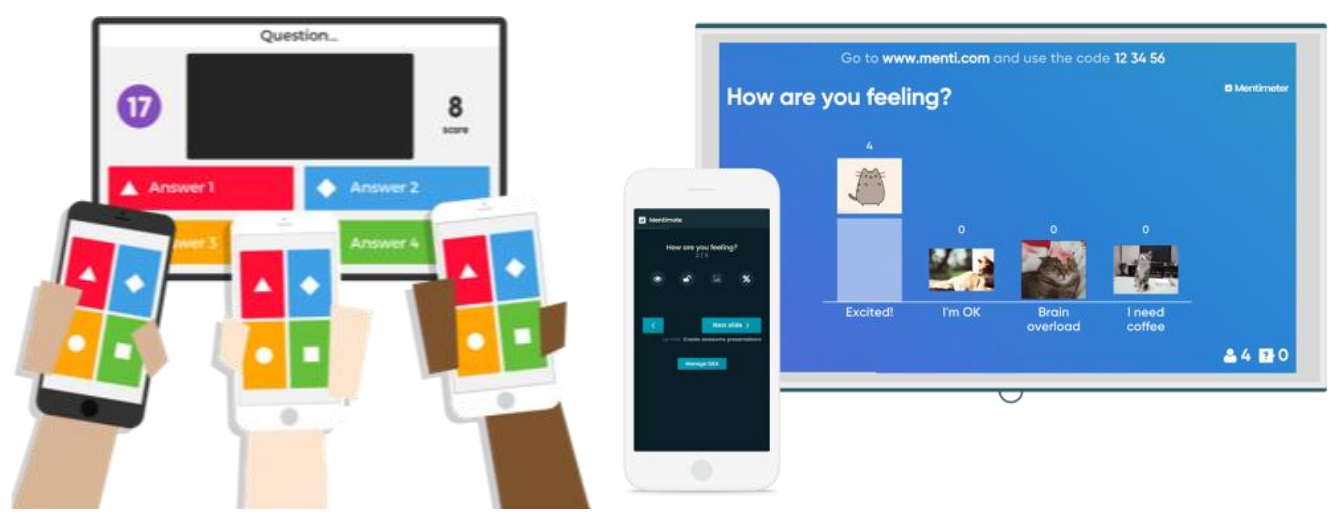

\section{A nyitott tananyagfejlesztés szerepe}

A Budapesti Műszaki és Gazdaságtudományi Egyetemen múködő MTA-BME Nyitott Tananyagfejlesztés Kutatócsoport munkája során számos új koncepció került kidolgozásra, melyek jól integrálhatók az eddig bemutatott módszertani megoldásokkal és technológiákkal. A koncepció egy aktív hallgatói/tanári részvétellel megvalósuló tartalomfejlesztés, mely folyamatban a képi tanulás és 
a gyakorlati oktatás közötti erős és szerves kapcsolat alakítható ki. Ebbe as folyamatba sokszor a tanulók is bevonhatóak.

Módszertani szempontból egy tananyag tartalmazhat szöveget ( $\mathrm{t}$ ), vizuális elemeket (v), matematikai formulákat (M) vagy esettanulmányokat (C). Ezen tartalmak tudáselemekbe, mikrotartalmakba szervezhetők (L1...L3) melyek által összeáll a tananyag virtuális tere. A nyitott tananyag-struktúrák esetén a tananyag egységek közé akár újabb elemek is beépülhetnek, a különböző hallgatói kiegészítési opciók pedig aktív közremúködéssel a hallgató, tanár számára az alkotás lehetőségét is biztosító eljárás, melynek a motivációs hatása is jelentős. (Benedek, 2016)

\section{9. ábra: Tudáselemek egymáshoz kapcsolódása az Nyitott Tananyagfejlesztés koncepcióban [12]}

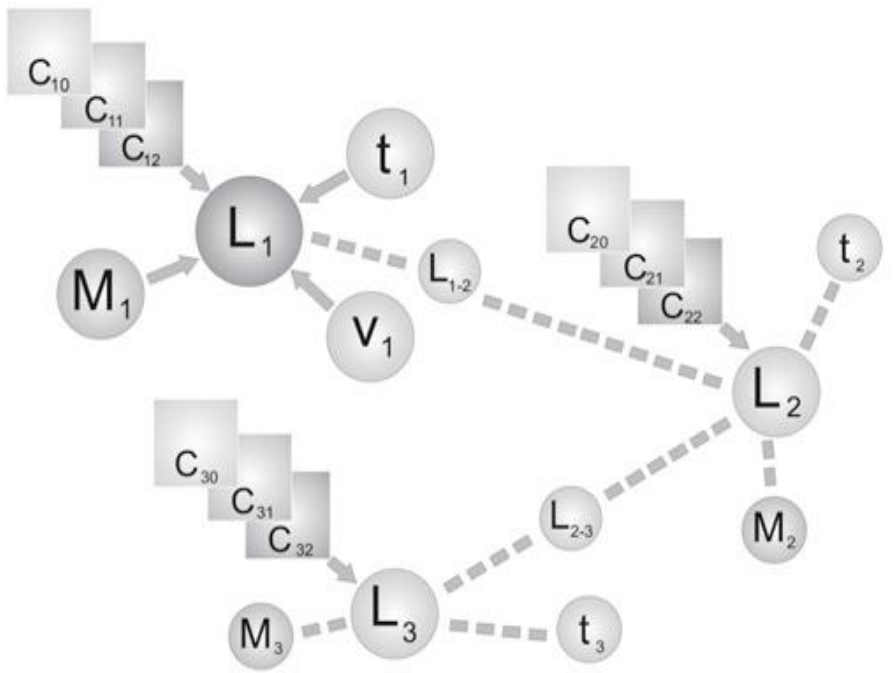

A mikrotartalmak kezelésére több felületet is létrehozott a kutatócsoport - melynek tagjai a jelen munka szerzői is - szakmacsoporttól, felhasználói köröktől és képzéstől függően. Az OCD Moodle felületén és az MC HUNGLE rendszerben a Nyitott Tananyagfejlesztő képzésben résztvevő pedagógusok tudnak mikrotartalmakat összeállítani. (OCD ajánlat, 2018) Az MC HUNGLE rendszerben rajtuk kívül az elsőéves villamosmérnök és mérnökinformatikus hallgatók tudják elkészíteni mikrotartalmaikat. (Horváth Cz., 2016) A legújabb Mikro-tartalom kezelő közösségi rendszer használatával a Rendszerelméletet tanuló mérnök- és közgazdásztanár hallgatók tudják elkészíteni a mikrotartalmaikat, valamint értékelni egymás munkáját. Végül a Sysbook hallgatói munkák felületére a Szabályozástechnikát tanuló mérnökinformatikus hallgatók, illetve a Rendszerelméletet tanuló mérnök- és közgazdásztanár hallgatók tudják elkészíteni a mikrotartalmaikat.

A bemutatott trendeket felismerve és követve a Sysbook és MC HUNGLE rendszerhez a böngészős megjelenítési és szerkesztési lehetőségek mellett elkezdtük egy kapcsolódó okostelefonos alkalmazás fejlesztését, ami ki tudja használni a készülékekben rejlő szenzorok, valamint a hordozhatóság és kompaktság erősségeit.

\section{Mikrotartalmak kezelése okostelefonon}

Egy 2018 őszén készült N=45 fős, középiskolásokat és elsőéves egyetemistákat célzó felmérés IKT eszközhasználati kérdéskörének eredményeiből kiderült, hogy a diákok egyre kevesebbet használják a helyhez kötött asztali számítógépeket (21 fónek nincs is) és egyre többen a hordozható eszközöket, főleg a laptopokat és okostelefonokat használják legtöbbet. Laptopja 11 fönek nincsen, a többiek 
átlagosan napi 2-3 órát használják. Okostelefonja mindenkinek van, 24-en több mint négy órán át használják napi szinten. A tabletek és okosórák elterjedtsége viszont nem számottevő.

\section{0. ábra: Napi IKT eszközhasználat különböző eszközökön}

\section{Mennyit használod naponta saját IKT eszközeidet?}

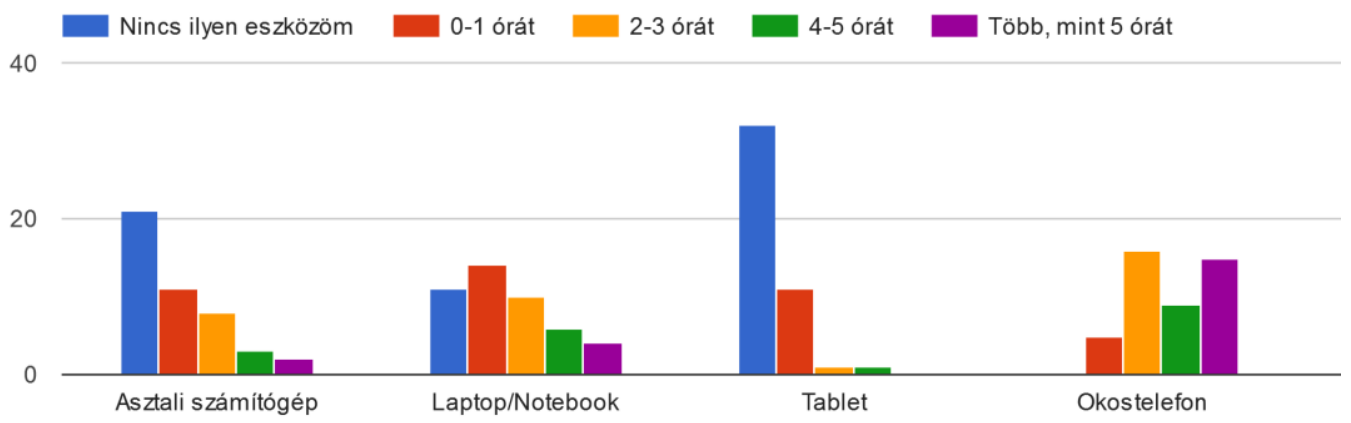

Az egyik platform, a Sysbook egy többszintű elektronikus tanulási környezet, ahol a különböző szintek közül az első „mindenkinek” szól, melyben képregényszerűen, ábrák és magyarázatok mutatják be a rendszerekkel és irányításukkal kapcsolatos fogalmakat. A második szint az „érdeklődő hallgatónak” szól, kapcsolódik az első szinthez is. A magyarázatokhoz matematikai leírás is tartozhat, amennyiben ez a jelenségek mélyebb megértését segíti. A harmadik szint az „irányítástechnikai szakembereknek” szól, az újabb rendszertechnikai és irányítástechnikai eredményekről, a trendekről. Ezeken felül esettanulmányok mutatják be, hogyan alkalmazható a rendszerszemlélet, illetve a szabályozási koncepciók különböző rendszerekben (autó, energiatermelés, orvostechnika, stb.).

\section{1. ábra: Sysbook az okostelefon képernyőjén}

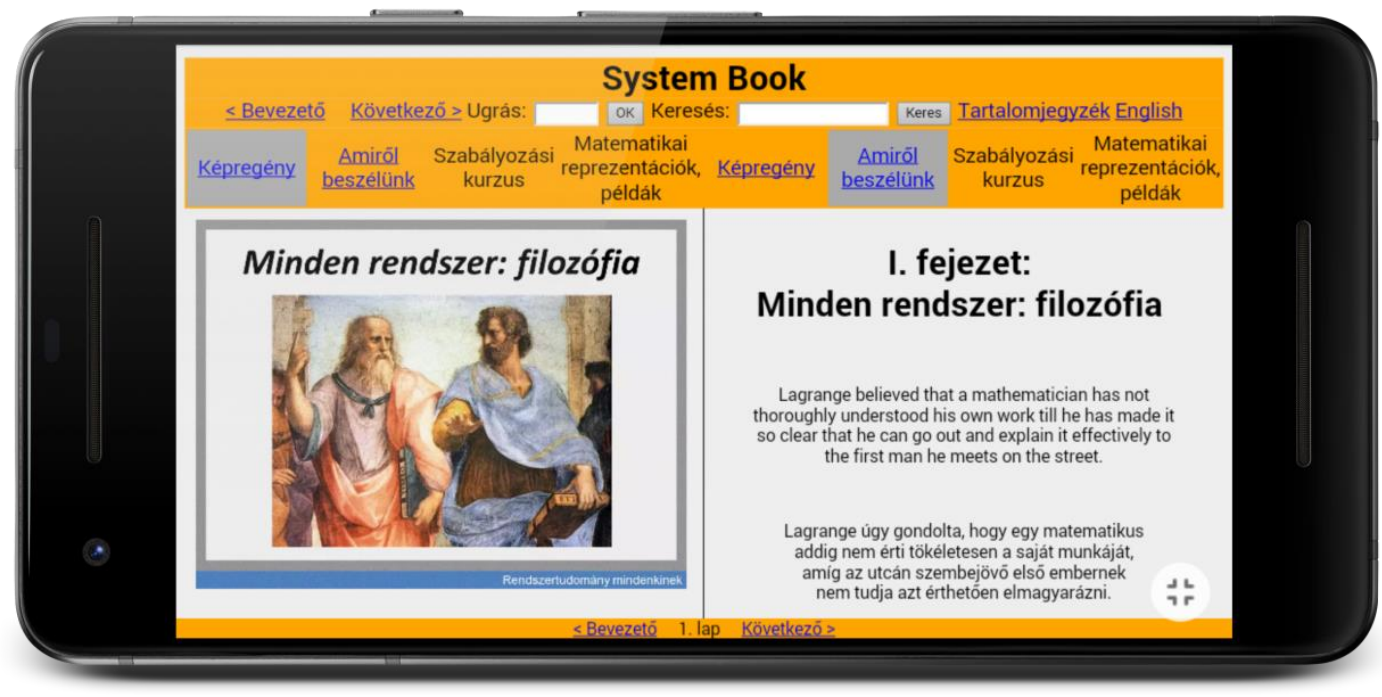

A nyitott tananyagfejlesztés keretében lehetőség nyílik hallgatói projektek, rövid esettanulmányok feltöltésére. Ezek a hallgatók által készített, rendszerszemléletet és irányítástechnikai szempontokat figyelembe vevő projektek, prezentációk, mikrotartalmak lehetnek, melyek elbírálás után jelennek meg a Sysbook Hallgató munkák felületén. (Vámos et al., 2017) 
A Sysbook támogatja a dinamikus tartalmak beágyazását és megjelenítését is, így például a mozgóképes animációkat, a felugró ablakos szómagyarázatokat, a Youtube-ról vagy Preziként beágyazott videókat, előadásokat, illetve interaktív Java és JavaFX alapú alkalmazásokat. Ezek az appletek az egyszerűbb szemléltető céloktól kezdve, akár az összetettebb szabályozási rendszerek megtervezését támogató céllal készültek el, és lettek elérhetővé téve a Sysbook felületén.

\section{2. ábra: Sysbook zsonglőr applet az okostelefon képernyőjén}

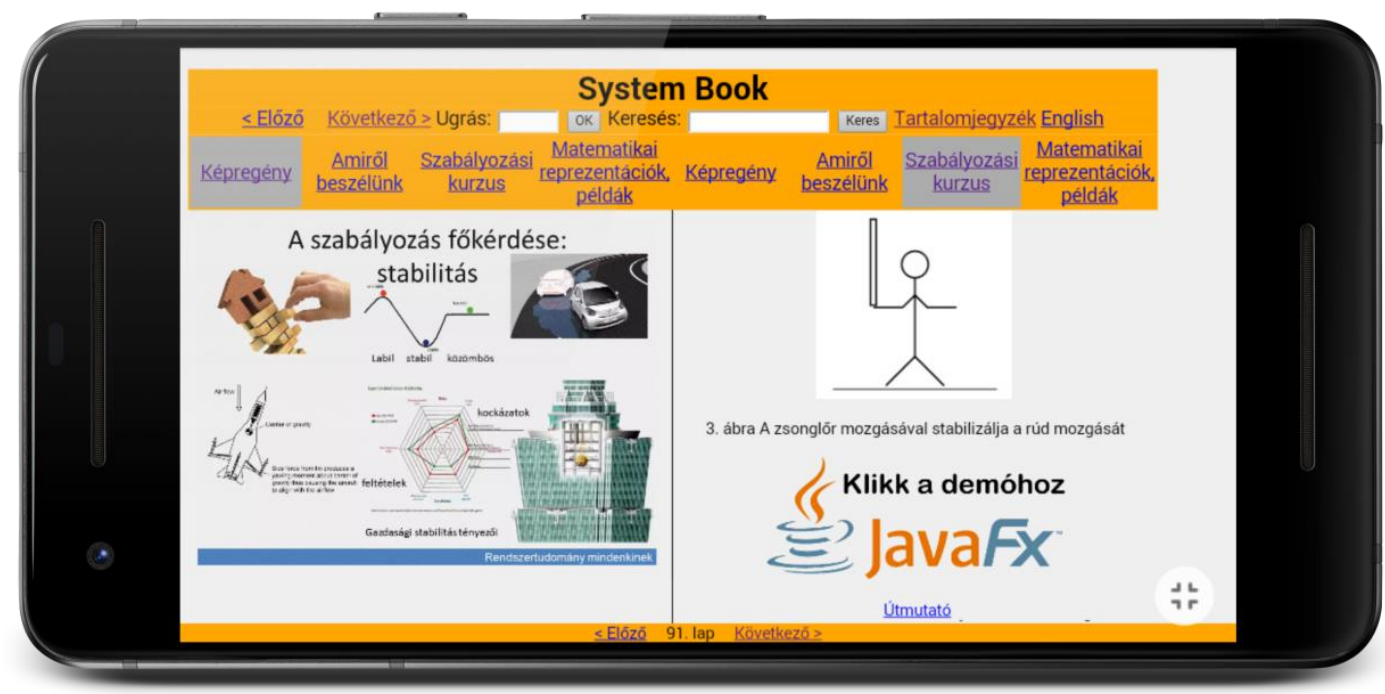

A Sysbook még nem egy külön alkalmazásban érhető el, hanem egy mobilböngészőre optimalizált változata tekinthető meg és használható bármely okostelefonra elérhető böngészőalkalmazáson keresztül.

Az MC HUNGLE rendszerhez már saját, natív, Android alapú alkalmazás fejlesztése kezdődött el, McApp néven, melyben kombinálásra kerültek a böngésző alapú (WebView) technikák, valamint az Android operációs rendszer kontextus függő funkciói. Itt különböző gesztusok segítségével érhetők el az egyes lehetőségek, így a menü megjelenítése, az egyes menüpontok kiválasztása és a velük kapcsolatos múveletek. Az alkalmazásban számos elérhető szenzoradat is felhasználásra került, így az okostelefon fényképezőgépével készült fotók lehetnek a mikrotartalmak vizuális tudáseleme, metaadatként hozzákapcsolhatjuk az éppen érvényes földrajzi koordinátáinkat, valamint mind a képernyőt, mind a virtuális billentyúzetet is használhatjuk adatbevitelre.

Az alkalmazás fejlesztésével cél volt a „Bring Your Own Device” (BYOD) szemléletmód erősítése is, melynek segítségével a felhasználók akár az adott óra vagy előadás alatt az oktató vagy pedagógus iránymutatása alapján, valós időben elérhetik a rendszert és készíthetik el saját mikrotartalmaikat. A közösségi funkciók révén pedig lehetőségük van a mikrotartalmak szerkesztésére és menedzselésére, a hallgatótársak által készített mikrotartalmak keresésére és megtekintésére, értékelésére vagy éppen megosztására. 
13. ábra: Az MC HUNGLE rendszer és az McApp alkalmazás
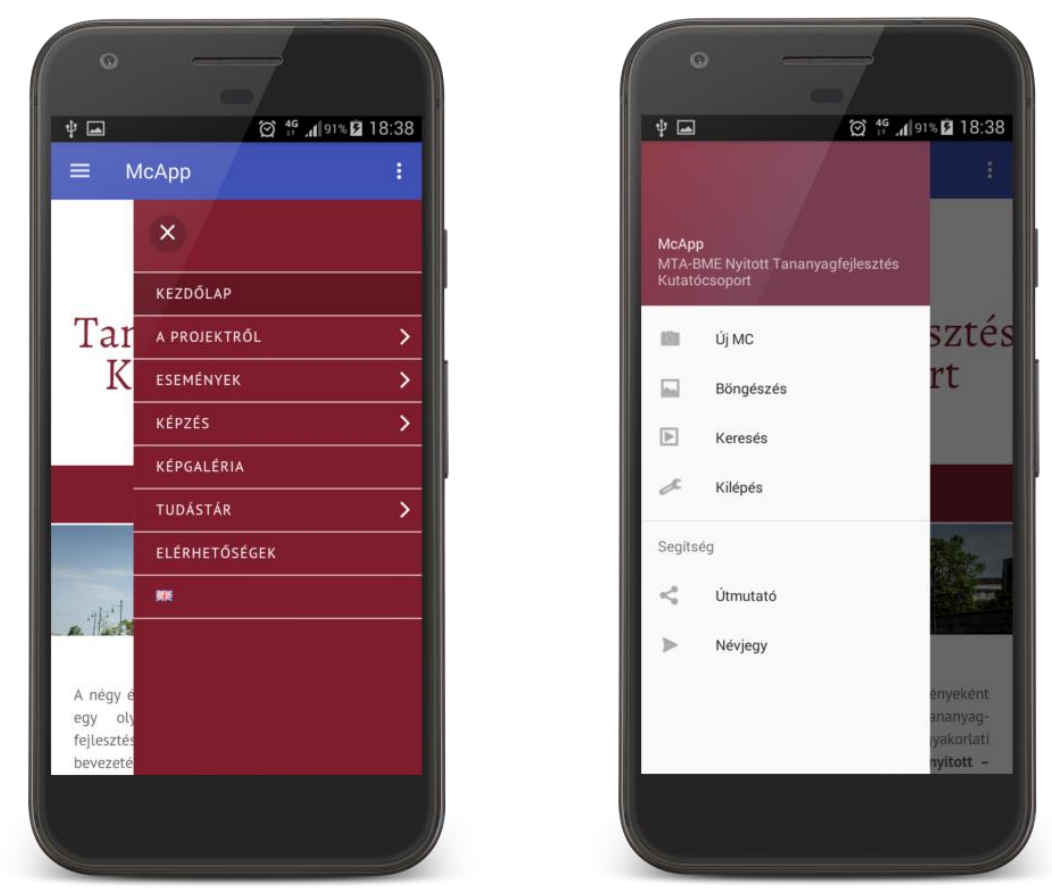

\section{Összegzés}

Írásunkban arra vállalkoztunk, hogy bemutassuk a napjainkra kialakult trendeket és ezek alkalmazhatóságát az okostelefonok, az atipikus oktatásmódszertani megoldások, valamint ezek kombinációjával kapcsolatban. Rámutattunk az okostelefonos operációs rendszerek Android dominanciájú piacára, az érintőképernyőből, a kommunikációs technológiákból és a szenzorok felhasználásából származó oktatási és tanulási céllal is alkalmazható lehetőségekre. Utaltunk számos atipikus módszertani lehetőségre, úgy mint a virtuális és kiterjesztett valóság alapú eszközökre, szimulációs lehetőségekre, valamint az élményalapú, interaktív gamifikációs megoldásokra. Ezt követően a nyitott tananyagfejlesztés koncepcióba beágyazva vizsgáltuk meg az okostelefon alapú megoldások létjogosultságát, használhatóságát, különös tekintettel a mikrotartalmak és hallgatói munkák megjelenítésére és további közösségi funkciókra. Az IKT eszközhasználati trendeket egy kapcsolódó felmérés segítségével is alátámasztottuk, mely alapján arra a következtetésre jutottunk, hogy a mai digitális bennszülöttek generációját legfőbbképpen az okostelefonok és applikációk segítségével tudjuk a legnagyobb mértékben megcélozni és elérni. Ezek segíthetnek a jövőbeli hatékony atipikus tanulási módszerek és eszközrendszerek meghatározásában.

\section{Köszönetnyilvánítás}

Az Emberi Erőforrások Minisztériuma ÚNKP-18-2 kódszámú Új Nemzeti Kiválóság Programjának támogatásával készült.

Az Emberi Erőforrások Minisztériuma ÚNKP-18-4 kódszámú Új Nemzeti Kiválóság Programjának támogatásával készült.

Az MTA-BME Nyitott Tananyagfejlesztés Kutatócsoport támogatásával készült. 


\section{Felhasznált szakirodalom}

- Benedek András (2016): „Nyitott tananyag-fejlesztési modell (OCD)” MTA-BME Nyitott Tananyagfejlesztés Kutatócsoport Közlemények.

- Benedek András (2016): „Új tanulási és tanítási módok a XXI. század első felében”, In: Tóth Attiláné, S. Gubik Andrea (szerk.) Magyarország 2025-ben és kitekintés 2050-re: Tanulmánykötet Nováky Erzsébet 70. születésnapjára. 299 p. Budapest: Arisztotelész Kiadó, 2016. pp. 133-142. (ISBN:978-615-5394-03-4)

- Horváth Cz. János (2016): „Micro-content Generation Framework as a Learning Innovation" In: Benedek, András; Veszelszki, Ágnes (szerk.) In the Beginning was the Image: The Omnipresence of Pictures: Time, Truth, Tradition. Frankfurt am Main, Németország: Peter Lang GmbH, Internationaler Verlag der Wissenschaften, pp. 171-181.

- Molnár György (2014): „Az újmédia digitális, időszerü, tartalmi kérdései” OktatásInformatika (ISSN: 2061-179X) (eISSN: 2061-1870) 2014: (2) pp. 29-39. (2014)

- Molnár György (2016): „Innovatív technológiai megoldások alkalmazása a tanárképzésben”, tanulmányok: A magyar nyelv, irodalom és hungarológiai kutatások intézetének kiadványa 2016:(1.) pp. 107-120.

- Molnár György, Szüts Zoltán, Biró, Kinga (2018): „Use of Augmented Reality in Learning” Acta Polytechnica Hungarica 15:5. pp. 209-222.

- MTA-BME Nyitott Tananyagfejlesztés Kutatócsoport - OCD ajánlat (2018): http://www.ocd.bme.hu/wp-content/uploads/2018/10/OCD-aj\%C3\%A1nlat-2018-v3.pdf

- Smartphone Market Share (2018): https://www.idc.com/promo/smartphone-market-share/os

- Szüts Zoltán (2018): „Online: Az internetes kommunikáció és média története, elmélete és jelenségei”, Budapest, Magyarország: Wolters Kluwer, ISBN: 9789632957784, pp 15-25

- Vámos Tibor, Bars Ruth, Benedek András, Sik Dávid (2017): „Sysbook Rendszerekről és irányításokról különbözö szinteken" MTA-BME Nyitott Tananyagfejlesztés Kutatócsoport Közlemények.

\section{Ábrák forrásai}

[1] https://www.statista.com/chart/4112/smartphone-platform-market-share/

[2] https://www.dreamstime.com/stock-illustration-icons-hand-gestures-smart-phonetouch-screen-tablet-image49577837

[3] https://www.rapidrepair.com/cp-iphone-4s.html

[4] https://www.hpreveal.com/products/index.html

[5] http://www.quivervision.com/apps/

[6] https://www.stuttgarter-zeitung.de/inhalt.hype-um-neues-smartphone-spiel-suechtignach-pok-mon-go.730aee06-5e08-44e8-9fd9-f87afa7c9afb.html

[7] https://developer.android.com/studio/run/emulator

[8] http://sine.ni.com/cs/app/doc/p/id/cs-14792

[9] https://index.hu/techtud/2018/11/22/a_szamitogep_feltamadasa/

[10] https://kahoot.com/what-is-kahoot/

[11] https://www.mentimeter.com/features

[12] http://www.ocd.bme.hu 